\title{
On the Ethics of Interpretation: are Young Readers to Blame?
}

\author{
INDRE் ŽAKEVIČIENE்
}

\begin{abstract}
The author of the article will discuss the problem of validity thinking about the basic statements of Literary Ethics. Though the problems Literary Ethics emphasizes are global and at the same time rather abstract, the efforts of literary researchers to educate readers with the help of novels are understandable but seem ineffectual. Young readers are not capable of understanding complicated texts of the previous century because of the different contents of their mental spaces or the different schemes of thinking. Literary Ethics speaks about the importance of the role of emotions while reading novels, but the spectrum of primary emotions young readers experience while reading complicated literary texts blocks all the ways to deeper understanding and the ability to analyze specific ethical issues encoded in the novels. The theory of emotions explains the situation and in a way rehabilitates young readers. Nevertheless, particular transformations of genres or of the original form of literary texts could evoke the readers' interest and make them think deeper or extend the realm of interpretations by relating particular "genre markers" and rethinking their codes.
\end{abstract}

Keywords: Literary Ethics; empirical experience; genre; novel; emotions

\section{Introduction}

Literary Ethics and Narrative Ethics could be treated as basic branches of literary research even in the postmodern era. The urge to pose questions never diminishes, and the possibility of looking for answers not only in everyday experience but also in literary texts is still available. The importance of literature was clearly defined by Joseph Meeker, whose ideas later inspired the researchers interested in Ecocriticism, a highly ethical sphere of scientific research: "Human beings are the earth's only literary creatures. [...] If the creation of literature is an important characteristic of the human species, it should be examined carefully and honestly to discover its influence upon human behavior and the natural environment [...] Is it an activity which adapts us better to the world or one which estranges us from it?” (Meeker 1997:3) It is rather difficult to measure the imaginable levels of adaptation or estrangement, but Literary 
On the Ethics of Interpretation: are Young Readers to Blame?

Ethics emphasizes the undeniable gain literature provides, that is, the ability to ask questions and to increase one's tolerance. On the other hand, literary texts and their perception are closely related to the problem of interpretation, which complicates theorethical assumptions and brings to the fore the question of validity. In his work "Redefining Ethical Criticism" American professor of English, Liberal Education and Pedagogy Marshall W. Gregory states:

No one can ever foresee exactly what sense, meaning, or application of any literary content that any particular reader may draw from any work, see in any work, or impose on any work. It follows that if no one can ever make confident predictions about what anyone else will make of a work of literary art, then claims about that work's allegedly inevitable effects are rendered impotent. (Gregory 2010)

Nevertheless, people who do interpret, analyze literature and speak about it may not even be aware of particular ethical theories. Literary Ethics is a unique sphere because of the multiplicity of attitudes and the subtle nuances of statements. Marshall W. Gregory emphasizes such subtlety while speaking about the influence of poetry and about the essential questions ethical criticism rises:

...will have I become a better person because of it [the poem]? This question is too crude and blunt to be of much help. Starting with this question would be like using a hammer to open a package with crystal goblets in it: you will smash the crystal out of all recognition before you even know what you are looking for. Better question: has an attentive engagement with this poem invited me to become in any way a different person than I was before, and, if it has, how do I identify the spots in the poem where I have said $>$ yes $<$ or $>$ no $<$ to its invitations, how do I identify what those differences are, and how do I evaluate their potential effect on my character? (Gregory 2010)

All those questions could be answered, but the most essential problem "attentive engagement" - is not so easy to be solved.

\section{How Wide is the Gap? Empirical Remarks}

The first problem to be discussed in the article is based on empirical experience and could be defined as the question of particular cognitive sphere: how could we speak about any ethical aspects of the text, if the so-called mental spaces of different generations differ? This difference becomes more and more noticeable 
while communicating with students. During a course in Comparative Literature (autumn semester in 2016) master students studying at Vytautas Magnus university were asked to interpret the picture "Descendant" by Pavel Kuczynski where the central figure is that of a black man in chains (http://www.pictorem. com/2100/Descendant.html) and their interpretations provoked another discussion with some people of an older generation; the students grasped the meaning of the picture quite differently from the members of an older generation and related the black man to hip-hop culture emphasizing the need of hip-hop artists to create their specific image using a lot of jewelry. Members of the older generation interpreted the picture in connection with slavery and with the inability to resist an ingrained and abnormal situation. Young people (the same as the elder ones) grounded their associations in their everyday experience or inn their particular mental schemes, which differ.

Here is one more example. The students were asked to analyse some lines

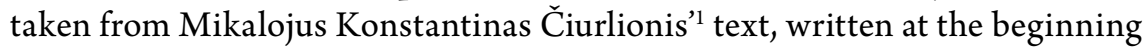
of the $20^{\text {th }}$ century: "When I felt tired after my race through the streets of a large city, I sat down on the bench, meant for messengers." (Čiurlionis) ${ }^{2}$ The image of the messenger was understood as a courier working in DPD, thus sweeping away the allusions to the spiritual and to more extended interpretations. Such "misunderstandings" or simply different interpretations can be easily explained having in mind the cognitive theoretical framework. As American psychologist Jerome Busemeyer states: "Cognitive science is concerned with understanding the processes that the brain uses to accomplish complex tasks including perceiving, learning, remembering, thinking, predicting, inference, problem solving, decision making, planning, and moving around the environment" (Busemeyer 2010: 1). Understanding literature could be treated as one of the tasks of the experts of cognition.

Gilles Fauconnier and Mark Turner have suggested the scheme of mental spaces with the explanation of the processes taking place in our mind while decoding metaphors or irony. The main elements of the scheme - generic space, input spaces and the blend - are clearly defined, but they signify rather complicated mental processes. "Generic spaces and blended spaces are related: blends contain generic structure captured in the generic space, but also contain more specific structure, and can contain structure that is impossible for the inputs [...]" (Fauconnier \& Turner 1998: 14). All the elements of the scheme

1 Mikalojus Konstantinas Čiurlionis (1875-1911) was well known Lithuanian painter and composer, who left some literary texts (literary miniatures and letters) written in Polish.

2 All the extracts of the texts are translated from Lithuanian by the author of the article. 
On the Ethics of Interpretation: are Young Readers to Blame?

("mental spaces"3) form a so called "conceptual integration network"; generic space is crucial here, because it contains all the experience and at the same time particular meanings (and future associations as well) of particular images. Those generic spaces are obviously characteristic of every individual and are not the same. Mental processes taking place during the act of reading may have the same pattern, but the interpretations will be stipulated by individual mental spaces, so how can the meaning of the text be grasped unambiguously? And if there is no unanimous way of understanding particular literary texts, how can we speak about a valid literary ethics? The theory itself is not to blame, but can the same text have particular ethical influence on every person equally?

\section{Literary Ethics: The Problem of Validity}

In his article "Cognition and Literary Ethical Criticism" Gilbert Plumer argues with Martha Nussbaum over the role of literature and the sympathetic imagination it provokes. Plumer states, that, according to Nussbaum, "life is generally neither wide nor deep enough. Nearly all of us cannot help but to live life mostly in a series of narrowly defined experiences; 'literature extends' this, she says, 'making us reflect and feel about what might otherwise be too distant for feeling' (Plumer 2011: 3). But in what ways could those extensions work having in mind cognitive questions and the meanings of simple literary images? Nussbaum and Plumer speak about the novel as the representative genre of evocative literature and emphasize three main formal features of the novel 1) "the novels show us the worth and richness of plural qualitative thinking"; 2) "the novels show us the priority of the particular"; 3) "the novel as form profoundly committed to the emotions; its interactions with the readers take place centrally through them" (Plumer 2011: 4). Here is an ideal situation; the novels do show us, but are we eager enough or capable of seeing? Empirical facts prove that the readers of younger generations most often have a specific horizon of expectations - they do like novels and prefer them to short stories or poetical texts, but those novels must be full of adventures, events and intrigues.

The fourth-year bachelor students were asked to read a Lithuanian novel by Bronius Radzevičius (1940-1980), Priešaušrio vieškeliai (Highroads Before the Dawn). The novel was written in the late 1970s and is treated as one of the

According to Fauconnier and Turner, "the input structures, generic structures, and blend structures in the network are mental spaces. Mental spaces are small conceptual packets constructed as we think and talk, for purposes of local understanding and action. Mental spaces are very partial assemblies containing elements, and structured by frames and cognitive models." (Fauconnier \& Turner 1998: 6) 
most famous Lithuanian existential novels of the Soviet period. Epistemological questions characteristic of modern literature are evident, "plural qualitative thinking" is basic here, but contemporary readers reject it as deadly boring and prolix. Yes, the novel is "profoundly committed to the emotions", but in this case to the emotions evoked - melancholy, sadness and irritation because of the disability to experience the pleasure of reading. Such primary personal emotions block the possibility to feel and see deeper. So are young readers to blame?

The answer could be suggested by the Russian psychologist Pavel Simonov and his Need-Informational Theory of Emotions, according to which the emotions experienced can be determined according to the formula $E=-N(I n-I a)$, where $E$ - "emotion, its degree, quality and sign, $N$ - the power and quality of the actual need in the broadest sense of the word (hunger, thirst, sex, social needs, the need to create, to satisfy curiosity and so on), In - information about the means prognostically necessary for satisfaction of the need; I - information about the means available to the individual at a given moment. "Information" refers to its pragmatic meaning that can be determined as the change in probability of goal achievement" (Simonov 1991: 103). If there is information enough, the emotion would be positive; if the information we need exceeds the available information, the emotion would be negative, or, in other words, according to Pavel Simonov himself, "a low probability of goal achievement leads to the negative emotions of fear, alarm, fury, grief; an increased probability of satisfaction as compared to an earlier estimation, generates positive emotions of pleasure, joy and encouragement" (Simonov 1991: 103).

The plot of Radzevičius' book is understandable for those who know the realia of Soviet times (the problem of kolkhozes, of the resistance of Lithuanian partisans), the narrative can be attractive for those who can distinguish the specific vocabulary of Lithuanians-Highlanders, living in the eastern part of Lithuania, but philosophical references in the context of depicted soviet everyday life remain mute to the readers of the new generation. Lack of information stipulates mild frustration and the ethical aspects of the novel remain undetected. But it does not mean that the Ethics of Literature is to be forgotten.

\section{Apparent Strategies of the Genre: Could Literary Ethics Be Beneficial?}

Thomas Stearns Eliot was speaking about the intentions of the author (and of his text) to evoke the alertness of a reader (Eliot 1953). It might be that such evoked alertness could enable deeper considerations on ethical questions. How 
On the Ethics of Interpretation: are Young Readers to Blame?

could this be done in the digital era? The genre of the novel remains the leading one. According to Plumer, "the novel aims at verisimilitude, while nonfictional narration (history, biography...) aims at veracity. Speaking at a high level of generality, a novel's believability seems to be determined mostly by what can be called the 'internal' and 'external' coherence of the event complex" (Plumer 2011: 6). Verisimilitude may manifest itself through the modifications of the genre; therefore we can assume that the genre varied in form could contribute to the phenomenon of verisimilitude and to the alertness evoked. The parallels between narrative Ethics and genre theory could be useful in this case.

When defining Narrative Ethics, James Phelan emphasizes four main issues the ethics of the told, the ethics of the telling, the ethics of writing and the ethics of reading or reception (Phelan 2013). All these issues encompass a number of questions about the characters, their actions, conflicts, choices, about the events in the text, about implied authors, narrators and audiences, narrative techniques. In their article "To Describe Genres: Problems and Strategies" (2001) Maria Antonia Coutinho and Florencia Miranda solve the problem of the genre as an abstract category and suggest some concepts useful for defining the interrelations between onthological genre and empirical text. Such concepts as "parameters of genre", "mechanisms of textual realization" and "genre markers" could be related to Phelan's ethics of the telling. According to Coutinho and Miranda,

the parameters of genre are fixed as empirical texts through what we have assigned as mechanisms of textual realization. These mechanisms concern the management of the semiolinguistic resources of a text. [...] The same parameter will be able to be brought up to date through different mechanisms, and it is in the specificy of the mechanisms that the singularity of each text is rooted. (Coutinho and Miranda 2001: 41)

The authors explain the concept of "genre marker":

The notion of genre marker notices the functioning of the mechanisms of textual realization in the procedure of reception/interpretation of the texts. The mechanisms function like (or work like) genre markers as they are going to identify the lines that are associated specifically to a genre (Coutinho and Miranda 2001: 42).

Particular aspects of the ethics of the told - particular mechanisms of textual realisation - could be treated as specific genre markers and therefore could be 
more easily grasped and interpreted. So it could be said that the genre marker is treated in two ways - as a function and as a concrete formal expression.

Icchokas Meras' book Ant ko laikosi pasaulis (On Whom the World Stands, $1965)$ is presented as a novel-ballad and Dalia Jazukevičiūtès Jo vardas Sibiras (His Name is Siberia, 2013) as a romance. The Encyclopedia Britannica defines ballad as a short narrative folk song or any narrative composition suitable for singing; and romance is a "literary form, usually characterized by its treatment of chivalry". Obviously both novels are enriched by additional meanings and at the same time emotions, provoked by the so-called hypogenres or "parameters associated with different genres. These parameters can be observed through the mechanisms that materialize them" (Coutinho and Miranda 2001:42). In Meras' novel-ballad those parameters are vivid in the text plan - almost every chapter ends with short passages, which resemble poetical texts (allusions to the ballad).

$\begin{array}{ll}\text { And people understood. } & \text { Ir žmonės jau suprato. } \\ \text { Only she alone did not. } & \text { Tikji viena - ne. } \\ \text { What? Fired? } & \text { Ką? Šaudè? } \\ \text { No... } & \text { Ne... } \\ \text { Milk of hers, the mother's? } & \text { Jos, motinos, pieną? } \\ \text { The warmth of her - the mother's - hands? } & \text { Jos, motinos, rankų šilumą? } \\ \text { No! } & \text { Ne! }\end{array}$

(Meras $1965: 63)$

A coffin, and a gun?

Those are always together. What else do people need?
Karstas ir ginklas?

Jie visada drauge.

Ko dar žmonèms reikia?

(Meras $1965: 120)$

The novel is written as a peculiar report of the interrogator or the one who is interrogated, and so one more hypogenre is incorporated. Every chapter begins with a "hand-written" sentence - the answer of the witness.

An assumption could be made that the reader will not resist the need to look deeper (in case s/he is familiar with the formal characteristics of the ballad and does not suffer from the lack of information), and the questions of the ethics of the told will be answered.

Jazukevičiūtè's romance is based on the functional parameter of the genre; in other words, the empirical text is nuanced by the onthological genre of the romance, which may or may not be decoded. The narrator decides to disclose her love story, which started in her early childhood. She fell in love when she was five years old and in her early thirties she married her first and only love. Ethical questions are provoked, discussions on morality are generated, but 
On the Ethics of Interpretation: are Young Readers to Blame?

most often young people (the first-year bachelor students) treat the plot of the book as vulgar and unbelievable. Their astonishment most often shades those additional meanings stipulated by the indicated self-referential genre marker (the romance), but, on the other hand, their opposition to the events depicted provokes ethical considerations. The result is almost the same - the author of the book dared to speak about unusual or queer experiences under the shield of the norms of the genre, and the reader was able to feel deeper (though may be not always according to the predictable intentions of the author). By the way, the author begins her romance with an episode, which could illustrate the aims of the experts of Literary Criticism; the narrator speaks about particular evenings in her childhood, when she used to tell various stories to her sister and read various books herself:

On that evening I was reading The $\mathrm{Clogs}^{4}$. About a small child, who was playing with dried beans and flageolets. He had no other toys. Big beans - the cows and the horses, and small ones - the sheeps. This child thinks he is a shepherd. He pastures his stock in the grassland. But nevertheless I do know that he pastures the beans, and because of that I want to cry a bit. [...] This book touches me" (Jazukevičiūtè 2013: 9).

The narrator clearly feels the boundary between the imaginable world and reality, but chooses the emotionally charged pole of literature.

The conclusion is very simple: the ethics of the told is inscribed in literary texts, but particular cognitive aspects, emotional attitudes or preconceived expectations play their role. Nevertheless it seems that peculiar complications of the genre (in this case of the novel) could evoke the alertness of young readers and revive their ethical attitudes.

\author{
Indrè Žakevičienè \\ indre.zakeviciene@vdu.lt \\ Vytauto Didžiojo universitetas \\ Lituanistikos katedra \\ V. Putvinskio 23 - 201, \\ Kaunas LT-44243 \\ LIETUVA / LITHUANIA
}

4 The Clogs is a book by the Lithuanian author Kazys Saja (1932). This book was very popular in the seventies and later. 
ŽAKEVIČIENĖ

\section{Works Cited}

Busemeyer, J. R., Diederich, A. 2010. Cognitive Modeling. Los Angeles, London, New Delhi, Singapore, Washington DC: Sage Publications.

Čiurlionis, M. K. Pasaka. - http://ciurlionis.eu/literatura/lt-pasaka/ (15.11.17).

Coutinho, M. A., Miranda, F. 2001. To Describe Genres: Problems and Strategies. Ch. Bazerman, A. Bonini, D. Figueiredo, eds., Genre in a Changing World. Fort Collins, Colorado: The WAC Clearinghouse and Parlor Press, 35-55, https://wac. colostate.edu/books/genre/chapter3.pdf (15.09.16).

Eliot, T. S. 1953. Selected Prose. London: Penguin Books.

Encyclopaedia Britannica, https://www.britannica.com/ (31.01.17).

Fauconnier, G., Turner, M. 1998. Conceptual Integration Networks. - Cognitive Science, 22: 2, 133-187. Available at http://www.cogsci.ucsd.edu/ faucon/BEIJING/CIN. $\operatorname{pdf}(04.09 .16)$.

Gregory, M. W. 2010. Redefining Ethical Criticism. The Old vs. the New. - Journal of Literary Theory, http://www.jltonline.de/index.php/articles/article/view/287/879, Vol 4, No 2 (10.09.16).

Jazukevičiūtè, D. 2013. Jo vardas Sibiras. Vilnius: Alma littera.

Meeker, J. 1997. The Comedy of Survival: Literary Ecology and a Play Ethics. Tucson: University of Arizona Press.

Meras, I. 1965. Ant ko laikosi pasaulis. Vilnius: Vaga.

Phelan, J. 2013. Narrative Ethics. - The living handbook of narratology, http://www.lhn. uni-hamburg.de/article/narrative-ethics (17.11.17).

Simonov, P. V. 1991. Thwarted Action Needed - Informational Theories of Emotions. International Journal of Comparative Psychology, 5, 2, http://escholarship.org/uc/ item/344805ks (10.09.16). 